\title{
The Dominance of the Agency Model on Financing Decisions
}

\author{
Bramantyo Djohanputro \\ PPMSchool of Management, Indonesia
}

\begin{abstract}
There are some issues about how companies consider their financing. These issues are related to the amount, source, type, and the structure of such financing. So far, there is no uniform model that is able to explain how companies deal with these issues. There are three competing, dominant theories of financing decision making, i.e. the Pecking Order Theory, the Static Trade-off Theory, and the Agency Model Theory. This study attempts to explore which theory explains the best way for companies in the consumer industry to decide their financing method. There are five hypotheses to be tested in this study. Using data from public listed companies on the Indonesian Stock Exchange from 2008 to 2011, it seems that the Agency Model Theory is more dominant than the other two theories in explaining the way companies fulfill their financing needs.
\end{abstract}

\begin{abstract}
Abstrak: Terdapat beberapa isu terkait bagaimana perusahaan mempertimbangkan kebutuhan pendanaan mereka. Isu-isu yang terkait dengan pertimbangan tersebut adalah mengenai jumlah, sumber, jenis, dan struktur pendanaan. Sejauh ini, tidak ada model yang seragam yang mampu menjelaskan bagaimana perusahaan menangani isu tersebut. Terdapat tiga teori yang saling bersaing dan dominan terkait keputusan pendanaan, yaitu teori pecking order, static trade-off, dan agency model. Studi ini berusaha menggali teori mana yang terbaik menerangkan cara perusahaan di dalam industry konsumsi memutuskan pendanaan mereka. Terdapat lima hipotesis yang diuji di dalam studi ini. Dengan menggunakan data perusahaan terbuka di Bursa Efek Indonesia dari tahun 2008 sampai 2011, tampak bahwa agency model theory lebih dominan dalam menjelaskan cara perusahaan memenuhi kebutuhan pendanaan mereka dibandingkan dengan kedua teori lainnya.
\end{abstract}

Keywords: agency model theory; capital structure; corporate finance; pecking order theory (POT); trade-off theory

JEL classification: G00

* Corresponding author's e-mail: brm@ppm-manajemen.ac.id 


\section{Introduction}

There are some issues about how companies decide their financing methods. Such a decision is not only concerned with the amount that can be obtained but also with the source, type, and the structure of the financing. In dealing with these issues, companies may consider some of the underlying factors in financing, such as the availability of funds, the cost of capital, and the ability to control the company.

A theoretical point of view is needed to explain how and why practitioners behave in a certain way in fulfilling their financing needs. For example, some Chief Financial Officers (CFOs) and boards of directors may decide their financing needs on the basis of a benchmarking approach, i.e. by following how their peers determine their financing needs, especially for the capital structure. This may be one reason why companies in an industrial group tend to have similar capital structures because they adjust their capital structures to reflect those of their peers. Other CFOs determine the capital structure on the basis on their capacity to generate income or cash flows to fulfill their obligations. The more the companies have the capacity to generate an operating cash flow, the greater is their capacity to service their borrowing.

Academicians provide several alternatives to explain practitioners' behavior in such cases. There are three competing, dominant theories that explain how financing needs and capital structures should be determined. The theories are the Pecking Order Theory (POT), the Agency Model Theory (AMT) of capital structure, and the Static Trade-off Theory (STT). According to the (POT), a company attempts to obtain capital on the basis of the ease with which it can be accessed, starting with the easiest source. The
$\mathrm{CEO}$ and executive directors put some effort into negotiating with the non-executive directors or with the board of commissioners regarding how much net profit should be retained, as retained earnings, and how much is to be distributed as dividends. If retained earnings, which are the easiest source of financing that can be obtained, are exhausted, then they must start searching for other sources of financing.

The AMT on Capital Structure emphasizes the idea of improving the discipline of the board of directors in managing their company. A company with a higher profit needs to be closely controlled to assure that the directors put the maximum effort into protecting the interests of the shareholders by maximizing the value of the company and by using the company's resources wisely. One way of improving their discipline is by asking creditors to provide loans to the company and, as a consequence, closely control it. The creditors need to assure that the company is well managed and, as a result, their loans are safe.

The STT, on the other hand, assumes that a company attempts to maintain a certain Debt to Equity Ratio (DER). Companies who apply this theory believe that a certain ratio contributes to the efforts to maximizing the value of the company, as long as such a ratio results in the minimum level of the Weighted Average Cost of Capital (WACC or simply COC) or the maximum value of the firm.

The use of these models by practitioners may vary from one region to another, and across time (Rafiq et al. 2008). As an implication, some researchers have focused their studies on specific industries (Shanmugasundaram 2008; Jahan 2014; Kühnhausen and Stieber 2014; Mwangi et al. 
2014). In the case of Indonesia, choosing a basic industry sector for this study was based on the fact that the chosen industry was not heavily regulated and played in a free, competitive, market. No single company used in this study belongs to the government. This is one indication that the industry works under market-mechanisms. Therefore, the CFOs or Board of Directors have the freedom to decide the sources of financing and their capital structure based on the companies interests.

Based on the aforementioned argument, this study attempts to answer the following question: is there any tendency for companies that operate in the basic industry sector to decide their sources of financing and their capital structure? This study indicates that the AMT seems to be more dominant than the other two theories.

This paper is organized as follows. The first section is the introduction. It is followed by a brief description on the previous studies on the Pecking Order, Agency Model, and ST'T of Capital Structure. This is then followed by the proposed models and hypotheses. The next section elaborates the data employed in this study and their analysis. This paper closes with the conclusion.

\section{Previous Studies}

Papers on testing the existence of only two theories, i.e. the POT and STT, are quite common. Myer (1984) tested whether companies tended to use the Pecking Order or Static Trade-off Theories. Myer argues that the STT emphasizes the existence of an optimal capital structure between debt and equity by emphasizing the optimum benefit and costs of various sources of financing. The absence of an optimal capital structure is assumed to follow the POT.
Graham and Harvey (2001), also tested the existence of those theories through a survey sent to CFOs. They emphasize the way that CFOs consider certain factors when they look for capital, whether they strictly set a target ratio, moderately set a target ratio, or do not have a target ratio. They reveal that not all CFOs have a target capital structure. While only ten percent of CFOs have a very strict capital structure, at least nineteen percent of the CFOs surveyed did not have a target ratio at all. Their research also indicates the existence of both the Pecking Order as well as the STT in the actual decision making process for financing.

Graham and Harvey (2002) and Acaravci (2015) also conducted research to prove the Pecking Order and Static Tradeoff Theories by designing one model that was able to explain the existence of both theories by employing several explanatory factors. Some of those factors explain the existence of the POT, while others explain the existence of the STT. Some other studies, such as the one conducted by Rafiq et al. (2008), employed the same factors to indicate the existence of either the Pecking Order or Static Trade-off Theories, depending on the signs of those factors, i.e. positive or negative signs. The models may have employed parametric as well as nonparametric models.

Some studies indicate the tendency toward a certain DER. Frank and Goyal (2004) found that a company tends to have similarities in the growth of debt and equity at the same pace. In other words, CFOs of those companies behave as if they use the STT as the basis of their financing decisions by maintaining the DER at a constant level.

However, following Wurgler (2002) and Welch (2003), the DER may deviate from its long target ratio, because of stock price movement, the timing of equity issuance, and the 
timing of debt issuance. Therefore, the DER based on market value as the dependent variable needs to consider the market-to-book ratio and the interest rate as the explaining factors of DER changes.

Myer and Majluf (1984), were followed by some fellow researchers, such as Frank and Goyal (2008); Neus and Walter (2008); and Getzmann et al. (2010) who placed emphasis on the Asymmetric Information Condition. This condition leads to the possibility of moral hazards and adverse selections. This means that firms generally give priority to internal rather than external sources of financing because internally generated capital is easier to negotiate and acquired than capital from outside, regardless of the quality of the companies. Based on this argument, companies tend to follow the POT in deciding their capital needs.

The studies aforementioned have similarities in terms of the variables and models applied. Most of them employed the change in debt as the dependent variable. Cash flow, profit, capital expenditure, and changes in working capital were the explanatory variables. A few of those studies added other independent variables in order to improve the robustness of the studies.

AMT, as an alternative to the Capital Structure Theory, stands by the principle that a company needs to incur costs to reduce it's agency problem (Sen and Oruc 2009). According to Vo and Nguyen (2014), this agency problem can be dealt with by two mechanisms. The first mechanism is by allowing top management to hold a portion of shares in the company to make them take proper care of the company (see also Morck et al. 1988). The second mechanism is by increasing the level of debt in order to improve the market discipline (see also Jensen, 1986). Sharehold- ers expect the senior management team to maximize the firm's value and shareholders' wealth. However, the senior management may behave in such a way as to exploit the opportunity to maximize their own interests. Therefore, shareholders need a model to control them in such a way that they are forced to behave on behalf of the shareholders' interests. This is the role of debt in a company.

The AMT puts the role of debt differently from that in the Pecking Order and Static Trade-off Theories. Under the AMT, debt becomes an instrument to control management. Under the POT, debt becomes a sources of capital after internal sources of capital are exhausted. Under the STT, debt becomes the balancing source of capital to keep the DER constant at a certain target ratio.

The AMT argues that the larger, more profitable companies tend to increase their debt. By doing so, creditors, as external parties, put a lot of effort into controlling the way senior management manage the companies. Even though the interests of the creditors are mainly for the safe and timely repayment of their loan, the way management control and manage certain areas of the company are forced to be in accordance with the interests of shareholders such as the companies' financial performance, the role of fiduciary, and the sustainability of the companies. The involvement of creditors may be costly but the costs may not exceed the benefits expected by the shareholders.

\section{Hypotheses and Models}

\section{Pecking Order Theory (POT)}

To prove the existence of the POT, this study employed three models. The first model, 
i.e. the simple one, used the financing deficiency on the change in debt. The financing deficiency is defined as the condition in which the investment required by the company exceeds the cash flow generated internally by the company. The source of the internal cash flow is profit. As the profit is not sufficient to fulfill the capital need, it implies that the company needs to receive a financial injection from outside. The source of such financing could be in terms of either debt or equity.

The way a company fills the deficiency, or the gap between profit and investment requirement, depends on several factors. In the first case, the deficiency of a company exists, i.e. earnings after tax or the net profit of company $i$ at year $t\left(\mathrm{EAT}_{\mathrm{i},}\right)$ is positive, but less that the investment required at time $t$. Under this circumstance, the company needs to acquire debt to fulfill the gap. At a certain level of investment need, the lower the $\mathrm{EAT}_{\mathrm{i}, \mathrm{r}}$, i.e. the wider the gap, the larger the amount of debt is needed, $\Delta \mathrm{D}_{\mathrm{i}, \mathrm{t}}$, to fill the gap. In other words, the lower the $\mathrm{EAT}_{\mathrm{i}, \mathrm{t}}$, the higher the $\Delta \mathrm{D}_{\mathrm{i}, \mathrm{t}^{*}}$

In the second case, the EAT $_{\mathrm{i}, \mathrm{t}}$ exceeds its investment requirement at year t. According to POT, the company puts EAT $_{\mathrm{i}, \mathrm{t}}$ as the first priority to fulfill the investment required. The excess of EAT $\mathrm{E}_{\mathrm{i}, \mathrm{t}}$ would be idle if it is kept in the company. Therefore, idle $\mathrm{EAT}_{\mathrm{i}, \mathrm{t}}$ will be used to repay a part of the debt in the first place. Therefore, the larger the $\mathrm{EAT}_{\mathrm{i}, \mathrm{t}}$ the lower is the debt. In other words, $\mathrm{EAT}_{\mathrm{i}, \mathrm{t}}$ has the opposite movement in the change in debt at time $t\left(\Delta \mathrm{D}_{\mathrm{i}, \mathrm{t}}\right)$. The higher the $\mathrm{EAT}_{\mathrm{i}, \mathrm{t}}$ the lower the $\Delta \mathrm{D}_{\mathrm{i}, \mathrm{t}}$.

In the third case, $\mathrm{EAT}_{\mathrm{i}, \mathrm{t}}$ is negative, i.e. the company suffers losses and does not generate an internal cash flow to fulfill the investment required. POT argues that the com- pany will attempt to obtain new debt to fill the investment required. Therefore, the $\mathrm{EAT}_{\mathrm{t}, \mathrm{i}}$ is negatively related to $\Delta \mathrm{D}_{\mathrm{i}, \mathrm{t}^{*}}$

The relationship of EAT $\mathrm{T}_{\mathrm{t}, \mathrm{i}}$ and $\Delta \mathrm{D}_{\mathrm{i}, \mathrm{t}}$, can be expressed mathematically as follows:

$\Delta \mathrm{D}_{\mathrm{i}, \mathrm{t}}=\mathrm{a}+\mathrm{bEAT}_{\mathrm{i}, \mathrm{t}}+\varepsilon_{\mathrm{t}}$

where

$\Delta \mathrm{D}_{\mathrm{i}, \mathrm{t}}=$ the change in debt of company $i$ at period $t$;

$\mathrm{EAT}_{\mathrm{t}, \mathrm{I}}=$ the profit after tax of company $i$ at period $t$,

$\varepsilon_{\mathrm{t}}=\quad$ the error term at time $t$.

Hypothesis1 $\left(H_{1}\right)$ : The earnings after tax of a company has a negative relationship with the change in debt.

Equation (1) can be slightly extended by putting the dividend under the following argument. Suppose a company has a positive $\mathrm{EAT}_{\mathrm{i}, \mathrm{t}}$, i.e. the company generates a profit at time $t$. Under most terms of credit, the company has to fulfill its repayment obligation of the existing debt as its first priority. In this case, the total debt decreases or $\Delta \mathrm{D}_{\mathrm{i}, \mathrm{t}}$ is negative. The remained profit will be reinvested in the company, and the residual of the profit will be distributed as dividend. Under these circumstances, the larger $\mathrm{EAT}_{\mathrm{i}, \mathrm{t}}$, may result in a larger $\operatorname{Div}_{i, t}$ and at the same time lower the debt.

The relationship of $\mathrm{EAT}_{\mathrm{i}, \mathrm{t}}$ and Dividend $_{\mathrm{i}, \mathrm{t}}$ toward $\Delta \mathrm{D}_{\mathrm{i}, \mathrm{t}}$ can be expressed as follows:

$$
\Delta \mathrm{D}_{\mathrm{i}, \mathrm{t}}=\mathrm{a}+\underset{(-)}{\mathrm{bEAT}_{\mathrm{i}, \mathrm{t}}}+\underset{(-)}{\mathrm{cDivi}_{\mathrm{i}, \mathrm{t}}}+\varepsilon_{\mathrm{t}}
$$

The aforementioned leads to the hypothesis formulation to prove the existence of POT as follows. 
Hypothesis2 $\left(\mathrm{H}_{2}\right)$ : The earnings after tax and payment of dividends by a company have a negative relationship with the change in debt.

The above model can be extended by putting in three other independent variables. Rafiq et al. (2008) applied the portion of tangible assets as an explanatory variable. They argued that more tangible assets provided better opportunities for companies to borrow because they can use those tangible assets as collateral. This study does not employ the tangibility of assets as an independent variable. Instead, the change of fixed and current assets are employed to explain the behavior of the change in debt. The increase in either fixed or current assets can be fulfilled, partially or wholly, by debt because those assets can be used as collateral.

Rafiq et al (2008) also applied the logarithm of asset as an explanatory variable. The purpose of using this variable was mainly to accommodate the size effect. Large companies tend to have more opportunities to borrow. They also proposed the impact of asymmetric information on the amount of debt. In a large company, insiders have more information than outsiders. Moreover, the price of equity in large firms tends not to be undervalued. Under this condition, management prefer to finance companies by using equity. As a consequence, the increase in debt is not as much as the increase in firm size.

$$
\begin{aligned}
\Delta \mathrm{D}_{\mathrm{i}, \mathrm{t}}= & \mathrm{a}+\mathrm{b}_{1} \mathrm{EAT}_{\mathrm{i}, \mathrm{t}}+\mathrm{b}_{2} \mathrm{Div}_{\mathrm{i}, \mathrm{t}}+\mathrm{b}_{3} \mathrm{FA}_{\mathrm{i}, \mathrm{t}}+ \\
& \mathrm{b}_{4} \mathrm{WC}_{\mathrm{i}, \mathrm{t}}+\mathrm{b}_{5} \mathrm{LA}_{\mathrm{i}, \mathrm{t}}+\varepsilon_{\mathrm{t}} \ldots \ldots \ldots \ldots \ldots \ldots \ldots \ldots \ldots \ldots \ldots \ldots \ldots
\end{aligned}
$$

where,

$\Delta \mathrm{D}_{\mathrm{i}, \mathrm{t}}=$ the change in debt,

$\Delta \mathrm{FA}_{\mathrm{t}, \mathrm{i}}=$ the change in fixed asset,

$\Delta \mathrm{WC}_{\mathrm{t}, \mathrm{i}}=$ the change in working capital,
$\operatorname{Div}_{\mathrm{t}, \mathrm{i}}=$ the dividend, and

$\mathrm{LA}_{\mathrm{t}, \mathrm{i}}=$ the logarithm of the total book value of assets of company $i$ at period $t$.

The last variable is to control the inducement of the size of the company.

POT expects the following results. $\Delta \mathrm{FA}_{\mathrm{t}, \mathrm{i}}$ and $\Delta \mathrm{WC}_{\mathrm{t}, \mathrm{i}}$ are expected to have a positive relationship with $\Delta \mathrm{D}_{\mathrm{t}, \mathrm{i}}$, in the sense that the demands for large investment tend to push the company to increase its borrowing. The increase in fixed and current assets provides a larger amount of assets that are available as collateral. Therefore, the increase in both types of assets may induce the increase of debt.

Dividend, $\Delta \mathrm{D}_{\mathrm{t}, \mathrm{i}}$ is expected to have a strong negative correlation with $\operatorname{Div}_{t, i}$ because a large dividend indicates a large amount of excess funds. Therefore, the company does not need to borrow money. A smaller dividend, or the absence of such, indicates a shortage of funds and therefore the company needs to borrow money and hence the $\Delta \mathrm{D}_{\mathrm{t}, \mathrm{i}}$ increases.

The coefficient of $\mathrm{LA}_{\mathrm{t}, \mathrm{i}}$ only indicates the accessibility of the creditor based on the size of the company. Larger companies tend to exploit equity financing, instead of debt. They use debt to fill any lack of equity financing. Therefore, $\mathrm{LA}_{\mathrm{i}, \mathrm{t}}$ is expected to have a weak, positive relationship with the $\Delta \mathrm{D}_{\mathrm{t}, \mathrm{i}}$

In summary, based on Equation (3), POT expects the following results:

$$
\begin{aligned}
& \Delta \mathrm{D}_{\mathrm{i}, \mathrm{t}}= \mathrm{a}+\mathrm{b}_{1} \mathrm{EAT}_{\mathrm{i}, \mathrm{t}}+\mathrm{b}_{2} \mathrm{FA}_{\mathrm{i}, \mathrm{t}}+\mathrm{b}_{3} \mathrm{WC}_{\mathrm{i}, \mathrm{t}} \\
&(-)(+) \\
& \mathrm{b}_{4} \mathrm{Div}_{\mathrm{i}, \mathrm{t}}+\mathrm{b}_{5} \mathrm{LA}_{\mathrm{i}, \mathrm{t}}+\varepsilon_{\mathrm{t}} \ldots \ldots \ldots \ldots \ldots \ldots \ldots \ldots \ldots \ldots \ldots \\
&(-) \quad(+)
\end{aligned}
$$

Based on the Equation (4), the hypothesis to explore the evidence of POT is as follows: 
Hypothesis3 $\left(\mathrm{H}_{3}\right)$ : The change in debt has a strong negative relationship with the dividend but a moderate or low positive relationship with the change in fixed assets and the change in working capital.

\section{Agency Model Theory (AMT)}

As aforementioned, the AMT argues that a company with a higher profit encourages the management to borrow funds from creditors. In this case, shareholders feel more secured in terms of the safety of their wealth held by the management team because they are under the scrutiny of the creditors. The higher portion of debt in their capital, the tighter the creditors supervise and monitor the management.

The above argument can be expressed statistically as follows:

$$
\Delta \mathrm{D}_{\mathrm{i}, \mathrm{t}}=\mathrm{a}+\mathrm{b}_{1} \mathrm{EAT}_{\mathrm{i}, \mathrm{t}}+\varepsilon_{\mathrm{t}}
$$

where

$\Delta \mathrm{D}_{\mathrm{i}, \mathrm{t}}=$ is the change in debt; and

$\mathrm{EAT}_{\mathrm{i}, \mathrm{t}}=$ the earnings after tax or net profit of company $i$ at time $t$.

As mentioned earlier, under AMT, shareholders attempt to control the company through creditors. The larger the profit gained by the company, the larger the debt of the company. Creditors always put efforts into monitoring the company closely to assure that the company maintains its creditworthiness through it's financial, operational, strategic, and managerial healthiness.

The hypothesis related to Equation (5) is as follows:

Hypothesis4 $\left(H_{4}\right)$ : The change in debt has a strong positive relationship with the earnings after tax.
Following Dudley (2007), Leland (1994), and Breman and Schwartz (1978), a more complete form of AMT is modeled as follows:

$$
\begin{aligned}
\Delta \mathrm{D}_{\mathrm{i}, \mathrm{t}}= & \mathrm{a}+\mathrm{b}_{1} \mathrm{EAT}_{\mathrm{i}, \mathrm{t}}+\mathrm{b}_{2} \mathrm{FAR}_{\mathrm{i}, \mathrm{t}}+ \\
(+) & (+) \\
\mathrm{b}_{3} \mathrm{LA}_{\mathrm{i}, \mathrm{t}}+\varepsilon_{\mathrm{i}, \mathrm{t}} & \ldots \ldots \ldots \ldots \ldots \ldots \ldots \ldots \ldots \ldots \ldots \ldots \ldots \ldots \ldots \ldots \ldots \ldots \\
(+) &
\end{aligned}
$$

$\mathrm{FAR}_{\mathrm{i}, \mathrm{t}}$ is the fixed asset ratio of company $i$ at year $t$, i.e. the ratio of fixed assets to total assets. This variable has two meanings. Firstly, a higher ratio indicates the higher capital requested. Under AMT, a company tends to finance the investment in fixed assets from debt in order to enhance the control. Dudley (2007), Leland (1994), and Brennan and Schwartz (1978) put another meaning to this ratio. According to them, $\mathrm{FAR}_{\mathrm{i}, \mathrm{t}}$ represented bankruptcy costs. The higher the ratio, the lower the bankruptcy costs. It is because creditors have collateral in case of bankruptcy. Therefore, a higher $\mathrm{FAR}_{\mathrm{i}, \mathrm{t}}$ makes creditors feel comfortable to provide loans and, as a result, increase debt.

The variable $\mathrm{LA}_{\mathrm{i}, \mathrm{t}}$ in AMT has a similar meaning to that in POT. Large companies tend to have better access to creditors. Therefore, the amount of debt is expected to have a positive relationship with the size of the company.

Hypothesis5 $\left(\mathrm{H}_{5}\right)$ : The change in debt has a strong positive relationship with the earnings after tax, and a moderate, positive relationship with the fixed asset ratio.

\section{Static Trade-off Theory (STT)}

The hypotheses for the STT are developed as follows. A company with a huge $\mathrm{EAT}_{\mathrm{i}, \mathrm{t}}$ may use this net profit in different 
ways, depending on the opportunities available to it. Under the condition of the absence of investment opportunities, the company tends to distribute the money as dividends or keep it in the company as a reserve. However, if the company has an opportunity to invest, it will deploy the money to be invested in fixed as well as current assets. The larger the investment opportunity to be captured, the larger the $\mathrm{EAT}_{\mathrm{i}, \mathrm{t}}$, portion will be to be allocated for investment. According to the STT, every investment must be financed by equity and debt to keep the capital ratio stable. In other words, the larger the $\mathrm{EAT}_{\mathrm{i}, \mathrm{t}}$, the larger the debt to fulfill the demand for investment.

A company that suffers losses can do nothing to grasp an investment opportunity. The only possibility it has is to divest or sell some assets to fulfill its need for cash. Under a loss condition, the total book value of equity decreases. Under STT, the company has to reduce its debt to keep the DER constant. Therefore, the sale of assets will provide the cash needed for operations and, at the same time, to repay a part of the debt. This leads to the following conditions. The first condition, negative $\mathrm{EAT}_{\mathrm{i}, \mathrm{t}}$, is accompanied by negative $\Delta \mathrm{D}_{i, t}$ when the company suffers losses and, at the same time, reduces its debt. In other words, the $\mathrm{EAT}_{\mathrm{i}, \mathrm{t}}$ has a positive relationship with $\Delta \mathrm{D}_{\mathrm{i}, \mathrm{t}}$. The second condition, the $\mathrm{EAT}_{\mathrm{i}, \mathrm{t}}$ is negative but the company does not want to reduce its size, i.e. the company does not want to sell a part of its assets and does not reduce its debt. This is unlikely to happen under STT because this decision leads to the deviation of the DER from its target.

The above arguments can be expressed mathematically as follows:

$\Delta \mathrm{D}_{\mathrm{i}, \mathrm{t}}=\mathrm{a}+\mathrm{bEAT}_{\mathrm{i}, \mathrm{t}}+\varepsilon_{\mathrm{t}}$
Equation (7) proposes that a higher $\mathrm{EAT}_{\mathrm{i}, \mathrm{t}}$ provides more equity for investment. Therefore, the debt must be increased to fulfill the investment in order to keep the DER at a certain or targeted level. The lower EAT $_{\text {i, }}$ also leads to a lower need for additional debt. Therefore, the positive relationship is expected to be considerably strong.

The above explanation leads to the following hypothesis under STT

\section{Hypothesis $6\left(H_{0}\right)$ : The change in debt has a moder- ate, positive relationship with earnings after tax.}

A company may suffer losses but finds an investment opportunity and needs to invest in fixed or current assets. Under STT, the company may seize the investment opportunity by issuing shares to obtain new equity and, at the same time, obtain a new loan to accompany the new shares to keep the DER constant. This decision leads to a positive relationship between the change in debt and the change in equity. This relationship can be modeled in a statistical Equation 8 as follows:

$\Delta \mathrm{D}_{\mathrm{i}, \mathrm{t}}=\mathrm{a}+\mathrm{b} \Delta \mathrm{E}_{\mathrm{i}, \mathrm{t}}+\varepsilon_{\mathrm{t}}$

With $\Delta \mathrm{E}_{\mathrm{i}, \mathrm{t}}$ being the change in book value of equity of company ${ }_{i}$ at time ${ }_{i}$ The hypothesis, then, is as follows:

Hypothesis $7\left(\mathrm{H}_{7}\right)$ : The change in debt has a strong, positive relationship with the change in equity.

$\Delta \mathrm{E}_{\mathrm{i}, \mathrm{t}}$ depends on internal equity financing and external equity financing. Internal equity financing is reflected by the $\mathrm{EAT}_{\mathrm{i}, \mathrm{t}}$ and $\mathrm{DIV}_{\mathrm{i}, \mathrm{t}}$. External equity financing is reflected by $\mathrm{NEF}_{\mathrm{i}, \mathrm{t}}$, the amount of new equity financing from external sources by the issue of new shares. Hence, $\Delta \mathrm{E}_{\mathrm{i}, \mathrm{t}}$ in model (8) can be re- 
placed by $\mathrm{EAT}_{\mathrm{i}, \mathrm{t}}$, DIV $\mathrm{i}_{\mathrm{i}, \mathrm{t}}$ and $\mathrm{NEF}_{\mathrm{i}, \mathrm{t}}$. Furthermore, other variables employed in model (4) are also applicable to test STT. Therefore, Equations (7) and (8) can be combined and extended as Equation 9.

$$
\begin{aligned}
& \Delta \mathrm{D}_{\mathrm{i}, \mathrm{t}}=\mathrm{a}+\mathrm{b}_{1} \mathrm{EAT}+\mathrm{b}_{2} \operatorname{Div}_{\mathrm{i}, \mathrm{t}}+\mathrm{b}_{3} \mathrm{NEF}_{\mathrm{i}, \mathrm{t}}+ \\
& (+) \quad(-) \quad(+) \\
& \mathrm{b}_{4} \Delta \mathrm{FA}_{\mathrm{t}, \mathrm{i}}+\mathrm{b}_{3} \Delta \mathrm{WC}_{\mathrm{t}, \mathrm{i}}+ \\
& (+) \quad(-) \\
& \mathrm{b}_{5} \Delta \mathrm{LA}_{\mathrm{t}, \mathrm{i}}+\varepsilon_{\mathrm{t}} \\
& (+)
\end{aligned}
$$

Under STT, the dependent variable $\Delta \mathrm{D}_{\mathrm{i}, \mathrm{t}}$ is expected to have a strong relationship with the first three independent variables. The increase in debt is needed if the company has retained earnings, i.e. earnings after tax $\left(\mathrm{EAT}_{\mathrm{i}, \mathrm{t}}\right)$ minus dividends $\left(\operatorname{Div}_{\mathrm{i}, \mathrm{t}}\right)$. It is because if the company does not increase its debt, the capital structure will change and this situation violates (STT). At the same time, the increase in new equity financing $\left(\mathrm{NEF}_{\mathrm{i}, \mathrm{t}}\right.$, must be responded to by an increase in debt, to keep the DER stable.

The change in debt is also expected to have a positive relationship with the change in fixed assets as well as the change in working capital. Every penny invested in fixed and current assets must be financed by both equity and debt. Therefore, the increase in assets must be responded to by the increase in debt. This argument also applies the other way around. The decrease in assets needs to be responded to by reducing both equity and debt to keep their ratios as constant as possible.

The relationship between the change in debt and the size of the company under ST'T is similar to that under POT. The hypothesis is, then, as follows.
Hypothesis8 $\left(H_{8}\right)$ : The change in debt has a strong, positive relationship with earnings after tax, new equity financing, changes in fixed assets, and changes in working capital; a strong, negative relationship with dividends, and a moderate, positive relationship with the size of company.

\section{Data and Analysis}

Following Rafiq et al. (2008), Shanmugasundaram (2008), Jahan (2014), Kühnhausen and Stieber (2014), and Mwangi et al (2014) aforementioned, this study focused on testing the existence of POT, AMT, and STT in an industry or strategic group in a certain time period. A strategic group consists of companies that have similarity in terms of their business aspects, mainly in their types of products, markets, and business models. Some studies indicate that companies within a strategic group tend to have a similarity in their capital structures due to several factors, such as the behavior of creditors (Sen and Oruc 2009). According to them, the deviation from the industry average of capital structure is overcome by adding or reducing the debt. As a result, this action has an effect on the market's reaction (see, for example, Siegfried 1984; Harris and Raviv 1991; and Hatfield et al. 1994). However, some studies also indicate that certain strategic groups tend to have diverse financing resources (Almazan and Molina 2005; Kim 2008; Shanmugasundaram 2008). Various factors influence the divergence of capital structure (see, for example, Lev 1974; Mandelker and Rhee 1984; and Bradley et al. 1984). 
This study focused on the consumer goods industry in Indonesia due to two main reasons. Firstly, all the companies are independent companies, especially for deciding the amount, sources, and structure of their capital. This means that each of the boards of directors of these companies has the freedom to decide the capital required because of very limited regulations stipulated by the government. There are an appropriate number of listed companies in this industry and none of them are state-owned companies. Therefore, their funding decisions are expected to follow market mechanisms and, as a result, the behavior of the board of directors may reflect the theories to be tested. Moreover, the industry is in a competitive environment, meaning that their top management tend to make the best decisions for the companies. This study attempted to use for its data source as many public companies producing consumer goods which are listed on the Indonesian Stock Exchange as possible. After being screened, based on the availability of the data, there were 24 companies suitable for inclusion in this study. ${ }^{1}$

This study also specified the data only from a four years period, i.e. from 2008 to 2011. The period chosen was based on the fact that Indonesia faced an economic crisis in 2008, caused by the impact from the subprime mortgage crisis that started in the United States. Therefore, companies were expected to start preparing new financing strategies between 2008 and 2009, as part of their corporate strategies, to return the companies to a stable condition, i.e. years 2010 and 2011. Since some variables were in the process of change, such as the change in equity, in the end there was only a period of three years for the data employed in this study, i.e. the years 2009, 2010, and 2011.

Based on the industry and period chosen in this study, there are 72 items of data available from 24 companies. However, the absence of a time lag in the model leads to the treatment of the data as being similar to cross section data. Research with these 72 items of data and five independent variables fulfills the statistical requirement. As the panel data have the characteristics of time series data, the robustness of the interference is considered after regressions, i.e. whether the error fulfills the requirement of the robustness.

\section{Description of the Data}

The description of the data is shown in Appendix 1. The table shows the huge fluctuation of the changes in debt, $\Delta \mathrm{D}_{\mathrm{i}, \mathrm{t}}$, from negative to positive. This means that the companies may have reduced their debt at certain times and increased their debt at other times. EAT $_{\mathrm{i}, \mathrm{t}}$, one of the most important independent variables in this study, is always positive. However, the companies sometimes do not distribute dividends. In other words, they tend to accumulatec their profits as retained earnings.

The change of fixed and current assets also fluctuates considerably. Negative changes in fixed assets indicate that at least one company reduced its size of operations. This reduction leads to the reduction of the need for current assets too. It needs to be proven whether the reduction in its operations is balanced by the reduction of its debt or equity.

${ }^{1}$ The companies finally selected as the samples in this study are ADES, AISA, CEKA, DLTA, DVLA, GGRM, HMSP, INAF, INDF, KAEF, KDSI, KLBF, LMPI, MERK, MLBI, MRAT, MYOR, PYFA, RMBA, SKLT, STTP, TCID, ULTJ, UNVR. 
Appendix 1 also shows that $\Delta \mathrm{E}_{\mathrm{i}, \mathrm{t}}$ and $\mathrm{NEF}_{\mathrm{i}, \mathrm{t}}$ fluctuate strongly, from negative to positive. While negative $\Delta \mathrm{E}_{\mathrm{i}, \mathrm{t}}$ shows the reduction in the total book value of equity, negative $\mathrm{NEF}_{\mathrm{i}, \mathrm{t}}$ shows the reduction in the external equity. The external equity refers to paid-in capital and capital in excess. A negative $\mathrm{NEF}_{\mathrm{i}, \mathrm{t}}$ may indicate that a company takes a corporate action, such as stock buyback. This study did not intend to conduct research into the issue of corporate action. Instead, this study focused on the relationships between the change in debt, on one side, and the change in equity or net equity financing, on the other. Suffice to say here, that those fluctuations are interesting to explore in relation to the hypotheses under study.

This study also ran the Hausman tests for all the hypotheses. As the first step, both the fixed and random effects models of the Hausman tests were conducted. For comparison, this study reported the results for both the fixed and random effects models for every model tested, as can be seen in Appendix 1, Appendix 2, and Appendix 3. Appendix 1 shows the regression results to test the hypothesis of POT, Appendix 2 to test the hypothesis of AMT, and Appendix 3 to test the hypothesis of STT.

The majority of the regressions fit with the fixed effect model. Only two regressions fit with the random effect model. The Equation 1, i.e. the regression with $\mathrm{EAT}_{\mathrm{i}, \mathrm{t}}$ as the only independent variable in the model, indicated the fitness of the random effect model as well as the fixed effect model, as shown in Appendix 1. The regression result showed that EAT $_{i, t}$ had a positive relationship with $\Delta \mathrm{D}_{\mathrm{i}, \mathrm{t}}$ at a 5 percent significance level. Therefore, both the random and fixed effect models may be used to test the hypothesis.
The random effect model also applies to the last model for testing STT. The last two columns of Appendix 3 show the regression results of Equation (9) using the random and fixed effect models. The regression results clearly indicate that the model under the random effect model has the significant level of less than 1 percent while the model under fixed effect model is not significant to explain the relationships between the independent variables and the dependent variable. Therefore, the random effect model is used to prove the existence of the last hypothesis.

\section{Hypothesis Testing}

As formulated in the hypotheses, the regression results were used to test each hypothesis by looking at the signs and significant levels of the coefficients of the independent variables. We started with testing $\mathrm{H}_{1}$ to $\mathrm{H}_{3}$, to test for the existence of POT. The regression results are shown in Appendix 2. The test for $\mathrm{H}_{1}$ is shown in column (2) and (3). $\mathrm{H}_{1}$ says that earnings after tax have a negative relationship with the change in debt. However, the coefficient of $\mathrm{EAT}_{\mathrm{i}, \mathrm{t}}$ was positive and significant at a 5 percent significance level. Since the sign and the significance level of the coefficient were not as expected by POT, $\mathrm{H}_{1}$ is not proven. Hence, this Equation does not support the existence of POT.

Columns (4) and (5) of Appendix 2 show the results of regression to test the existence of $\mathrm{H}_{2}$. Adding $\mathrm{DDiv}_{\mathrm{i}, \mathrm{t}}$ as another explanatory variable, together with $\mathrm{EAT}_{\mathrm{i}, \mathrm{e}}$, was consistent with the above result, i.e. the nonexistence of POT. Both coefficients of the independent variables were expected to be negative, while the results were both posi- 
tive. The coefficient of $\mathrm{EAT}_{\mathrm{i}, \mathrm{t}}$ was positive and significant at the 5 percent significance level while the coefficient of $\Delta \operatorname{Div}_{\mathrm{i}, \mathrm{t}}$ was positive but not significant.

Columns (6) and (7) of Appendix 2 provide the regression results to test $\mathrm{H}_{3}$. The coefficient of $\Delta \mathrm{WC}_{\mathrm{i}, \mathrm{t}}$ was the only one that was strongly significant, i.e. at the 1 percent significance level. However, the sign was the opposite to the expected sign for POT. This means that the test to $\mathrm{H}_{3}$ was also consistent with the above two results, i.e. the nonexistence of POT.

The above tests clearly indicate that POT was not evident. In other words, it seems that POT does not fit in with the way the management of the companies within the consumer goods industry decided their capital needs. Even though a company has a high profit, the companies do not merely rely on the profit to fill the gap between the capital required and the capital available.

The tests for the existence of AMT were conducted by running the regressions that were in relation to hypotheses (4) and (5), as shown in Appendix 3. Columns (2) and (3) of Appendix 3 show the results of the regression of Equation (5) to prove $\mathrm{H}_{4}$. Hypothesis4 $\left(\mathrm{H}_{4}\right)$ says that the change of debt has a strong positive relationship with the earnings after tax. The coefficient of $\mathrm{EAT}_{\mathrm{i}, \mathrm{t}}$ was positive and significant at the 5 percent significance level. Based on this regression, it seems that AMT exists.

Columns (4) and (5) show the regression results to prove $\mathrm{H}_{5}$, saying that the change in debt has a strong positive relationship with the earnings after tax, and a positive relationship with the fixed asset ratio. Column (4) shows that the coefficients of $\mathrm{EAT}_{\mathrm{i}, \mathrm{t}}$ and $\mathrm{FAR}_{\mathrm{i}, \mathrm{t}}$ were both positive but none of them were significant. Column (5) shows slightly different results from column (4). The coefficient of EAT $\mathrm{T}_{\mathrm{i}, \mathrm{t}}$ was positive and had a 1 percent significance level, i.e. very strong, while the coefficient of $\mathrm{FAR}_{\mathrm{i}, \mathrm{t}}$ was negative but not significant. In this case, it seems that $\mathrm{H}_{5}$ is moderately accepted. Hence, $\mathrm{H}_{5}$ supports the existence of AMT but not very conclusively. Based on the results of testing both $\mathrm{H}_{4}$ and $\mathrm{H}_{5}$, it can be concluded that AMT seems to exist.

Appendix 4 shows the regression results to test for the existence of STT. Columns (2) and (3) show the regression results to test $\mathrm{H}_{6}$, saying that the change in debt has a moderate, positive relationship with earnings after tax. The results of the regression support this hypothesis, i.e. the coefficient of $\mathrm{EAT}_{\mathrm{i}, \mathrm{t}}$ was positive and had a 5 percent significance level. This means that higher profit is followed by higher debt.

Columns (4) and (5) of Appendix 4 provide different evidence. $\mathrm{H}_{7}$ says that the change in debt has a strong, positive relationship with the change in equity. Column (4) indicates that the coefficient of $\Delta \mathrm{E}_{\mathrm{i}, \mathrm{t}}$ was significantly negative, while column (5) indicates that the coefficient of $\Delta \mathrm{E}_{\mathrm{i}, \mathrm{t}}$ was positive but not significant. From the sign and significance level point of view, it is clear that $\mathrm{H}_{7}$ is not accepted. This also means that STT is not supported by this model.

Columns (6) and (7) of Appendix 4 show the regression results in relation to $\mathrm{H}_{8}$. This hypothesis says that the change in debt has a strong, positive relationship with earnings after tax, new equity financing, changes in fixed assets, and changes in working capital; a strong, negative relationship with dividends, and a moderate, positive relationship with the size of the company. The coefficients that support the hypothesis were the coefficients of $\mathrm{EAT}_{\mathrm{i}, \mathrm{t}}$, and $\mathrm{LA}_{\mathrm{i}, \mathrm{t}}$. The other coeffi- 
cients were not as expected by STT. Moreover, the coefficient of $\mathrm{NEF}_{\mathrm{i}, \mathrm{t}}$ was negative and significant under the random effect model. This was the opposite to the expected sign of the coefficient because under STT, higher debt has to be accompanied by higher equity financing. Therefore, this hypothesis was not fully accepted and, therefore, the regression result only weakly supported the existence of STT.

Based on the above analysis on the existence of POT, AMT, and STT, it is clear that AMT is superior to STT and POT in the way companies in the consumer industry in Indonesia deal with their financing and capital structure issues. The application of AMT in explaining the behavior of companies' financing and capital structure could be as follows. Companies tend to increase their loans when they earn profits. They do not intend to exploit the internally generated funds to become retained earnings. Instead, they obtain new loans to fulfill their financing needs to complement their retained earnings. This behavior seems to be in line with STT. However, companies keep increasing their loans, instead of increasing both loans and new external equity at a certain set proportion. They prefer to increase their loans by keeping paid in capital at a certain level. Based on AMT, the increase in loans when the companies are growing shows the aim of using their creditors' ability to control the companies.

The last important point to note from this study is the relationships between $\Delta \mathrm{D}_{\mathrm{i}, \mathrm{t}}$ and $\Delta \mathrm{FA}_{\mathrm{i}, \mathrm{t}}$ and $\Delta \mathrm{WC}_{\mathrm{i}, \mathrm{t}}$. Large companies have more opportunity and access to acquire debt. These loans need collateral. There are various types of collateral used in Indonesia, such as fixed assets, deposits in terms of back-toback loans, and personal guarantees. The weak relationship between the changes in fixed assets as well as current assets and the increase in debt may indicate that some companies are able to use something other than fixed and current assets as collateral.

\section{Conclusion}

Based on the aforementioned analysis, it may be concluded that: firstly, the POT does not work for companies within the consumer industry. In other words, their managers are not tempted to exploit profits to fulfill their financing needs. Supposing the POT worked, this would indicate that the management tended to exploit the sources of funds based on how easily the source of funds was accessible. As the POT does not apply to the consumer industry, that kind of behavior is not implemented in the industry. The management do not only put their efforts into obtaining capital based on how easily the capital is accessed, but there is at least one other consideration.

Another consideration, based on the evidence from the STT, is that the management needs to exploit other sources of capital, i.e. debt. The purpose of applying the STT is to minimize the cost of capital and, at the same time, to maximize the value of the firm by keeping the composition of debt and equity, or the DER at the most optimum level. Based on interviews with some financial managers, the increase in the use of the STT is probably due to the increase in the numbers of financial managers and CFOs with an educational background from financial academies. The increases in equity are balanced by the increased debt. This study does not involve itself in the study of the optimum DER. However, the significance of the increase in equity as well as the increase in net profits in relation to the increase in debt indicates such an effort. 
However, there is still another consideration, even more important than the value maximizing consideration, i.e. the control of companies by outsiders, mainly by their creditors. The AMT emphasizes the governance model, in the sense that the separation between principals and agents creates difficulties for principals to control the behavior of the agents. Principals have limited access to companies, therefore they encourage companies to borrow funds. Creditors always ask for as much information as they need before approving and disbursing any loans. Creditors want to make sure their funds are safe by evaluating the past performance of borrowers, evaluating the future or expected performance of the borrowers, and by designing a contract to assure that the borrowers' management behave properly to make sure the funds are secured and the companies are managed according to the investors' criteria. In this sense, shareholders are indirectly protected by the presence of creditors in the companies.

Therefore, the order that the theories are implemented in is as follows: The most important is the AMT, followed by the STT, and the least important is the POT.
Note that this order may be generalized for companies within the consumer industry in the Indonesian market. However, further generalization still needs other studies to be conducted in order to assure the validity and applicability of the findings when applied to other areas. There are some research alternatives, the first is to conduct similar studies based on different industries in the Indonesian market. If the findings of such studies are similar to the findings in this study, the generalization may be applied to the Indonesian market. If those findings diverge and differ, there may be a uniqueness to the financing decisions within different industry groups.

Secondly, studies could be conducted in similar industries in other markets, such as Singapore, Malaysia, and other neighboring countries. The third is to conduct studies in those countries in different industries. It may also be interesting to conduct similar studies in developed countries, in order to compare the results of such studies against the results of studies in Indonesia as a developing country. The purpose is to compare whether there are similarities and differences in financing decisions between developed vis a vis a developing country or countries.

\section{References}

Acaravci, S. K. 2015. The determinants of capital structure: Evidence from the Turkish manufacturing sector. International Journal of Economics and Financial Issues 5 (1): 158-171.

Ahmed, H. J. A., and N. Hisham, 2009. Revisiting capital structure theory: A test of pecking order and static order trade-of model from Malaysian Capital Market. International Research Journal of Finance and Economics 30: 58 - 65.

Almazan, A., and C. A. Molina. 2005. Intra-industry capital structure dispersion. Journal of Economics and Management Strategy 14 (2): 263-297.

Bradley, M., G. Jarrell, and E. H. Kim. 1984. On the existence of an optimal capital structure: Theory and evidence. Journal of Finance 39: 857-878. 
Brennan, M., and E. Schwartz. 1978. Corporate income taxes, valuation, and the problem of optimal capital structure. Joumal of Business 51 (1): 103-114.

Capozza, D. R., and P. J. Seguin. 1999. Leverage and value in apartment REITs. The National Multi Housing Council (the paper was accessed on 23 July 2011 at http://www.umich.edu/ reecon/restate/faculty/Capozza/Deb0899.pdf).

Frank, M. Z., and V. K. Goyal. 2004. The effect of market conditions on capital structure, adjustment. Financial Research Letter 1: 47-55.

Frank, M. Z., and V. K. Goyal. 2008. Trade off and pecking order theories of debt. In Eckbo, E. 2008, Handbook of Corporate Finance: Empirical Corporate Finance 2 (Chapter 12).

Getzmann, A., L. Sebastian, and K. Spremann. 2010. Determinants of target capital structure and adjustment speed - Evidence from Asian Capital Markets. Asian Finance Symposium Paper.

Graham, J. R., and C. R. Harvey. 2001. The theory and practice of corporate finance: Evidence from the field. Journal of Financial Economics 60: 187-243.

Graham, J. R., and C. R. Harvey. 2002. How do CFOs make capital budgeting and capital structure decisions? Journal of Applied Corporate Finance 15 (1): 8 - 23.

Harris, M., and A. Raviv. 1991. The theory of capital structure. Journal of Finance 46: 297- 355.

Hatfield, G. B., L. T. W. Cheng, and W. N. Davidson III. 1994. The Determination of optimal capital structure: The effect of firm and industry debt ratios on market value. Journal of Financial and Strategic Decisions 7.

Jahan, N. O. 2014. Determinants of capital structure of listed textile enterprises in Bangladesh. Research Journal of Finance and Accounting 5 (20): 11-20.

Jensen, M. C. 1986. Agency costs of free cash flow, corporate finance and takeovers. The American Economic Review 76: 323-329.

Kim, J-E. 2008. Strategic choice and financial structure in casual themed restaurants. Thesis, the Faculty of the Virginia Polytechnic Institute and State University (accessed on July 232011 on http:// scholar.lib.vt.edu/theses/available/etd-10292008-202447/unrestricted/joungeun.pdf).

Kühnhausen, F., and H. W. Stieber. 2014. Determinants of capital structure in non-financial companies. Discussion Paper of Department of Economics, University of Munich (accessed 8 April 2015, available on online at http:/ / epub.ub.uni-muenchen.de/21167//).

Leland, H. 1994. Corporate debt value, bond convenants, and optimal capital structure. Journal of Finance 49 (4): 1213-1252.

Lev, B. 1974. On the association between operating leverage and risk. Joumal of Financial and Quantitative Analysis: 627-641.

Mandelker, G. N., and S. G. Rhee. 1984. The impact of the degrees of operating and financial leverage on systematic risk of common stock. Journal of Financial and Quantitative Analysis 19 (1): 45-57.

Morck, R., A. Shleifer, and R. Vishny. 1988. Management ownership and market valuation. Journal of Financial Economics 20: 293-315

Mwangi, L. W., M. S. Makau, and G. Kosimbei. 2015. Relationship between capital structure and performance of non-financial companies listed in the Nairobi Securities Exchange, Kenya. Global Journal of Contemporary Research in Accounting, Auditing and Business Ethics 1 (2): 72-90.

Myers, S. C. 1984. The capital structure puzzle. Journal of Finance 39 (3): 575-592. 
Rafiq, M., A. Iqbal, and M. Atiq. 2008. The determinants of capital structure of the chemical industry in Pakistan. The Lahore Journal of Economics 13 (1): 139-158.

Shanmugasundaram, G. 2008. Intra-industry variations of capital structure in pharmaceutical industry in India. International Research Joumal of Finance and Economics 16: 1450-2887.

Siegfried, J. J. 1984. Effective average U.S. corporation income tax rates. National Tax Journal 27: 245-259.

Vo, D. H., and V. T. Nguyen. 2014. Managerial ownership, leverage and dividend policies: Empirical evidence from Vietnam's listed firms. International Journal of Economics and Finance 6: 274-284.

Welch, I. 2004. Capital structure and stock returns. Journal of Political Economy 112 (1). 
Gadjah MadaInternational Journal of Business-Maj-August,Vol 17,No. 2, 2015

APPENDIX 1. Descriptive Statistics of the Variables Under Study

\begin{tabular}{|c|c|c|c|c|c|}
\hline & $\begin{array}{c}\Delta \mathbf{D}_{\mathrm{i}, \mathrm{t}} \\
(\mathbf{R p} \text { Millins) }\end{array}$ & $\begin{array}{c}\text { EAT }_{\mathrm{i}, \mathrm{t}} \\
\text { (Rp Millins) }\end{array}$ & $\begin{array}{c}\text { Div }_{\mathrm{i}, \mathrm{t}} \\
\text { (Rp Millins) }\end{array}$ & $\begin{array}{c}\Delta \mathbf{E}_{\mathrm{i}, \mathrm{t}} \\
\text { (Rp millions) }\end{array}$ & $\begin{array}{c}\Delta \mathrm{FA}_{\mathrm{i}, \mathrm{t}} \\
\text { (Rp Millins) }\end{array}$ \\
\hline Mean & 168,547 & 924,427 & 907 & 599,152 & 188,896 \\
\hline Minimum & $(2,463,664)$ & 2,126 & 0 & $(364,482)$ & $(236,673)$ \\
\hline Maximum & $5,116,374$ & $8,051,057$ & 16,150 & $14,825,554$ & $4,080,407$ \\
\hline \multirow{2}{*}{$\begin{array}{l}\text { Standard } \\
\text { Deviation }\end{array}$} & 897,383 & $1,727,430$ & 2,900 & $1,986,117$ & 549,494 \\
\hline & $\begin{array}{c}\Delta W_{i, t} \\
\text { (Rp Millins) }\end{array}$ & $\begin{array}{c}\text { FAR }_{\mathrm{i}, \mathrm{t}} \\
\text { (percentage) }\end{array}$ & $\begin{array}{c}\mathbf{L} A_{\mathrm{i}, \mathrm{t}} \\
(\mathbf{R p} \text { Millins) }\end{array}$ & $\begin{array}{c}\mathrm{NEF}_{\mathrm{i}, \mathrm{t}} \\
\text { (Rp Millins) }\end{array}$ & \\
\hline Mean & 337,243 & $31.08 \%$ & 13 & 264,322 & \\
\hline Minimum & $(1,538,147)$ & $0.91 \%$ & 11 & $(176,614)$ & \\
\hline Maximum & $8,423,025$ & $62.03 \%$ & 16 & $12,916,171$ & \\
\hline $\begin{array}{l}\text { Standard } \\
\text { Deviation }\end{array}$ & $1,244,192$ & $13.81 \%$ & 2 & $1,608,241$ & \\
\hline
\end{tabular}




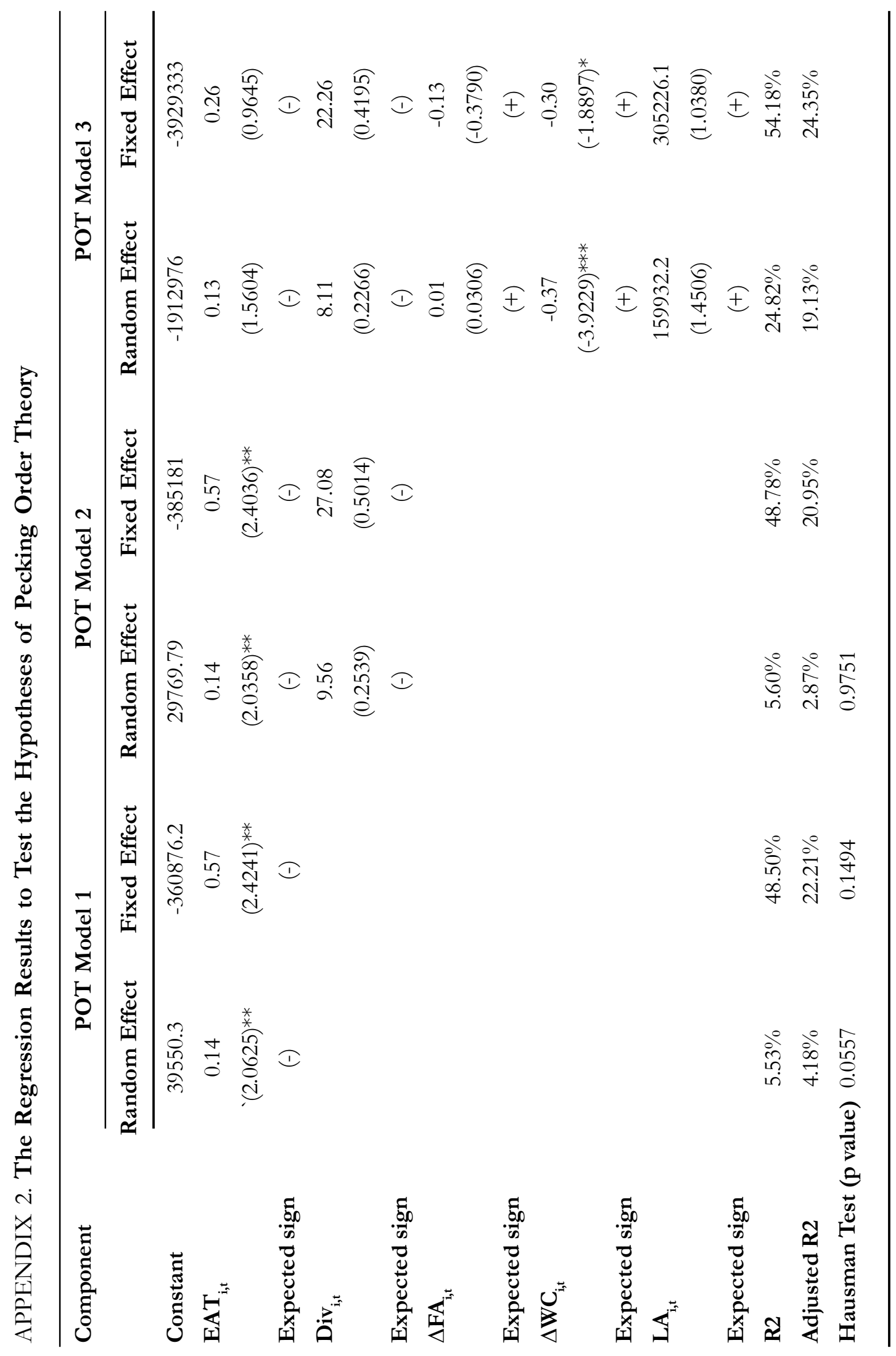




\section{APPENDIX 2. Continued}

\section{Notes:}

Appendix 2 provides the regression results in relation to $\mathrm{H}_{1}$, shown under columns POT Model 1, hypothesis 2, under columns POT Model 2, and $\mathrm{H}_{3}$, under columns POT Model 3. The equations of POT model 1 is

$$
\Delta D_{i, t}=a+b E A T_{i, t}+\varepsilon_{t} \quad \Delta D_{i, t}=a+b E A T_{i, t}+c D i v_{i, t}+\varepsilon_{t}
$$

$(-) \quad$, POT model 2 is (-) (-) , and POT model 3 is

$\Delta D_{i, t}=a+b_{1} E A T+b_{2} \Delta F A_{t, i}+b_{3} \Delta W C_{t, i}+b_{4} \operatorname{Div}_{t, i}+b_{5} L A_{t, i}+\varepsilon_{t}$

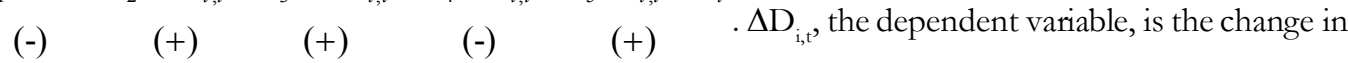

debt, $\mathrm{EAT}_{\mathrm{i}, \mathrm{t}}$, earnings after tax of company $i$ at time $t, \mathrm{DIV}_{\mathrm{i}, \mathrm{t}}$, dividend of company $i$ at time $t, \Delta \mathrm{FA}_{\mathrm{i}, \mathrm{t}}$ change in fixed assets of company $i$ at time $t, \Delta \mathrm{WC}_{\mathrm{i}, \mathrm{t}}$ the change in working capital of company $i$ at time $t$, and $\mathrm{LA}_{\mathrm{i}, \mathrm{t}}$ natural logarithm of Assets of company $i$ at time t. The table shows regressions of every equation using both random and fixed effect models. The figures in the table are the coefficients, and the figures in the parentheses are $t$-statistics, with (***) significance at 1 percent, $\left(^{* *}\right)$ significance at 5 percent, $\left(^{*}\right)$ significance at 10 percent. The signs $(-)$ and $(+)$ in the table are expected signs according the hypotheses. 
APPENDIX 3: The Regression Results to Test the Hypotheses of Agency Model Theory

\section{Component}

$\mathbf{L} \mathbf{A}_{\mathrm{i}, \mathrm{t}}$

Expected sign
AMT Model 1

AMT Model 2

\begin{tabular}{cccc}
\hline Random Effect & Fixed Effect & Random Effect & Fixed Effect \\
\hline 39550.3 & -360876.2 & -432529 & -5477774
\end{tabular}

$0.14(2.0625)^{* *} \quad 0.57(2.4241)^{* *}$

$0.13(1.3088)$

$0.48(1.9716)^{*}$

$(+)$

$(+)$

$(+)$

$(+)$

240630

$-1823820$

$(0.2767)$

$(+)$

$(+)$

31444.04

444750.10

$(0.2949)$

$(+)$

$(+)$

$50.99 \%$

$\begin{array}{llll}4.18 \% & 22.21 \% & 1.62 \% & 22.68 \%\end{array}$

0.1233

R2 $5.53 \%$

Adjusted R2

Hausman test (p value)

0.0557

\section{Notes:}

Appendix 3 provides the regression results in relation to $\mathrm{H}_{4}$, shown under columns AMT Model 1, and $\mathrm{H}_{5}$, under columns AMT Model 2. The equations of AMT model 1 is $\Delta D_{i, t}=a+b E A T_{i, t}+\varepsilon_{t}$

(+) , and AMT model 2 is $\Delta D_{i, t}=a+b_{1} E A T_{i, t}+b_{2} F A R_{i, t}+b_{3} L A_{i, t}+\varepsilon_{t}$

$(+) \quad(+) \quad(+) \quad . \Delta \mathrm{D}_{\mathrm{i}, \mathrm{t}}$, the dependent variable, is the change in debt, $\mathrm{EAT}_{\mathrm{i}, \mathrm{t}}$, earn-

ings after tax of company $i$ at time $t, \mathrm{FAR}_{\mathrm{i}, \mathrm{t}}$ the ratio of fixed assets to total assets of company $i$ at time $t$, and $\mathrm{LA}_{\mathrm{i}, \mathrm{t}}$ natural logarithm of Assets of company $i$ at time $t$. The table shows regressions of every equation using both random and fixed effect models. The figures in the table are the coefficients, and the figures in the parentheses are $t$-statistics, with (***) significance at 1 percent, $\left({ }^{*}\right)$ significance at 5 percent, $\left({ }^{*}\right)$ significance at 10 percent. The signs $(-)$ and $(+)$ in the table are expected signs according the hypotheses. 
Gadjah MadaInternational Journal of Business-May-August, Vol. 17,No.2, 2015

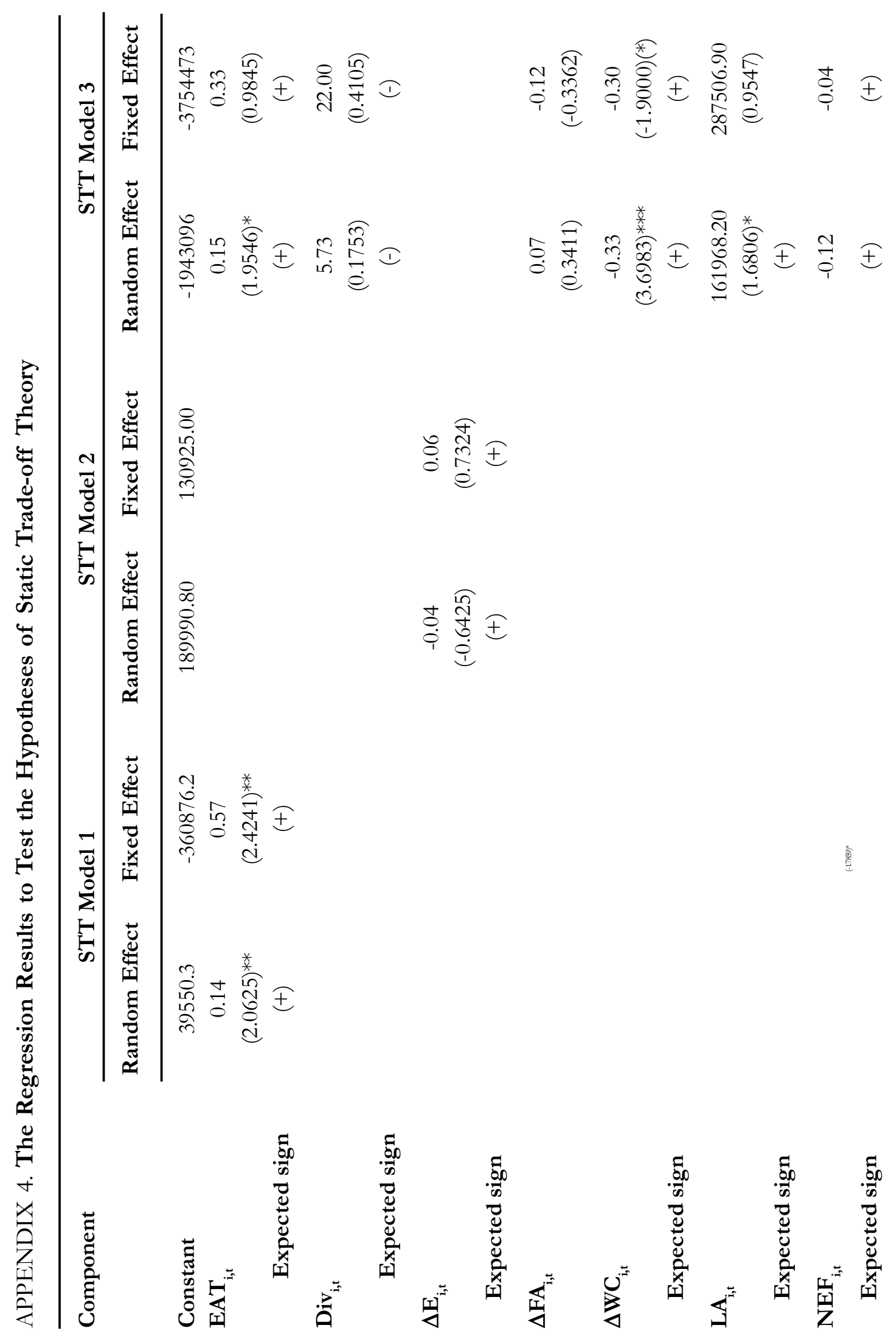




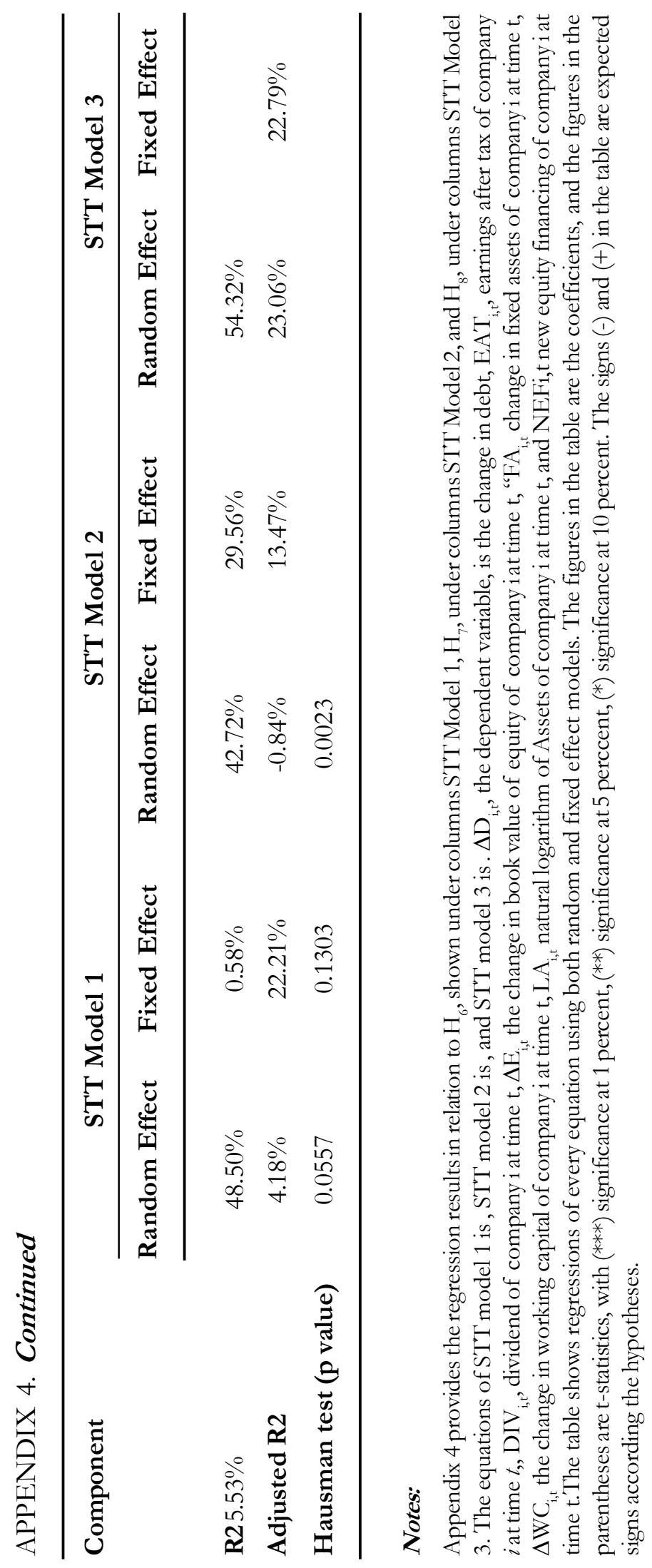

